\title{
PROGRAM BANTUAN KUOTA BELAJAR KEMENDIKBUD DI MASA PANDEMI
}

\author{
Bramastia \\ Program Studi Magister Pendidikan Sains Pascasarjana Fakultas Keguruan dan Ilmu \\ Pendidikan (FKIP) Universitas Sebelas Maret Surakarta \\ e-mail: bramastia@staff.uns.ac.id \\ Eka Khristiyanta Purnama \\ Koordinator Substansi Produksi Media Pembelajaran dan Pengembangan Teknologi \\ Pembelajaran (PTP) Ahli Madya Pusdatin Kemendikbud \\ e-mail: eka.khristiyanta@kemdikbud.go.id
}

\begin{abstract}
Abstrak
Kebijakan program Pusat Data dan Informasi (Pusdatin) Kementerian Pendidikan dan Kebudayaan (Kemendikbud) Republik Indonesia atas bantuan kuota internet gratis mendapat respon positif dari publik. Tujuan program bantuan kuota internet gratis untuk menilai respon publik terhadap kebijakan Kemendikbud Republik Indonesia. Dari data survei menunjukkan sebanyak 84,7\% publik menilai program bantuan internet gratis merupakan langkah tepat menjawab sense of crisis di tengah wabah corona (Covid-19). Sementara itu, sebanyak $85,6 \%$ publik menilai bahwa program bantuan internet gratis meringankan beban ekonomi orang tua pelajar atau mahasiswa dalam membeli paket internet. Bahkan, ada sebanyak $63,2 \%$ publik mengaku puas dengan kinerja Pusdatin Kemendikbud RI dalam menyalurkan bantuan kuota internet. Adapun platform belajar yang paling sering digunakan mulai dari platform Google Clasroom $(26,1 \%)$, Ruangguru $(17,1 \%)$ dan Rumah Belajar $(15,2 \%)$ menempati posisi tiga besar. Untuk penggunaan media video call dalam pembelajaran daring, mayoritas publik menggunakan aplikasi Zoom (57,2\%), disusul Google Meet $(18,5 \%)$ dan Cisco Webex $(8,3 \%)$. Masukan dari publik terkait kendala program kuota internet gratis diantaranya: memperbaiki signal internet tidak stabil $(23,8 \%)$, askes internet yang terbatas $(16,0 \%)$, pembagian bantuan harus lebih merata $(13,3 \%)$, jumlah kuota internet minim/kecil $(9,3 \%)$ serta perlunya pengawasan penggunaan $(5,1 \%)$. Kesimpulan program bantuan kuota internet gratis Kemendikbud Republik Indonesia memberikan kemanfaatan publik dan layak untuk dilanjutkan.
\end{abstract}

Kata Kunci: kuota internet gratis, kepuasan publik, kendala program

\section{PROGRAM ASSIST THE QUOTA LEARNING MINISTRY OF EDUCATION IN THE PANDEMIC PERIOD}

\begin{abstract}
The policy of the Data and Information Center (Pusdatin) program of the Ministry of Education and Culture (Kemendikbud) of the Republic of Indonesia for the assistance of free internet quota received a positive response from the public. The aim of the free internet quota assistance program is to assess the public's response to the policies of the Ministry of Education and Culture of the Republic of Indonesia. The survey data shows that as many as $84.7 \%$ of the public thinks that the free internet assistance program is the right step to answer the sense of crisis in the midst of the corona (Covid-19) outbreak. Meanwhile, as many as $85.6 \%$ of the public considered that the free internet assistance program had alleviated the economic burden on parents of students or students in buying internet packages. In fact, as many as $63.2 \%$ of the public admitted they were satisfied with the performance of the Indonesian Ministry of Education and Culture's Pusdatin in distributing internet quota assistance. The most frequently used learning platforms, starting from the Google Classroom platform (26.1\%), Ruangguru (17.1\%) and Rumah Belajar (15.2\%) occupy the top three positions. For the use of video call media in online learning, the majority of the public uses the Zoom application (57.2\%), followed by Google Meet (18.5\%) and Cisco Webex (8.3\%). Inputs from the public regarding the constraints of the free internet quota program include: fixing unstable internet signal (23.8\%), limited internet access (16.0\%), distribution of assistance must be more even (13.3\%), the amount of internet quota is minimal / small (9.3\%) and the need for supervision of use (5.1\%). The conclusion is that the free internet quota assistance program of the Ministry of Education and Culture of the Republic of Indonesia provides public benefits and deserves to be continued.
\end{abstract}

Keywords: free internet quota, public satisfaction, program constraints 


\section{PENDAHULUAN}

Pandemi yang sedang berlangsung ini menyebabkan sektor perekonomian yang tidak seimbang memiliki dampak pada proses pembelajaran yang dilakukan karena baik semua orang tua maupun guru pasti harus mengeluarkan dana lebih untuk menambah pengeluaran. Salah satu pengeluaran lebih tersebut untuk membeli kuota atau internet agar tetap berjalannya proses pembelajaran yang dilakukan pada masa pandemi, meskipun Kementerian Pendidikan dan Kebudayaan (Kemendikbud) Republik Indonesia akhirnya memberikan bantuan berupa subsidi kuota internet yang diberikan kepada guru, dosen, peserta didik dan mahasiswa, dengan tujuan supaya meringankan pengeluaran biaya.

Dari semuanya untuk membantu kuota mahal yang dikeluarkan baik oleh pendidik (guru dan dosen) maupun peserta didik (siswa maupun mahasiswa). Bahkan, guru juga mengalami kesulitan kuota internet dalam mengoreksi dan memeriksa setiap PR (Pekerjaan Rumah) yang diberikan pada peserta didik karena kapasitas ruang penyimpanan ponsel semakin terus berkurang dan banyaknya file yang harus diunduh dalam proses pembelajaran yang berlangsung saat ini.

Kebijakan Kemendikbud mengeluarkan program subsidi kuota internet bagi guru dan murid, serta mahasiswa dan dosen cukup signifikan. Program subsidi kuota internet ini dilaksanakan selama empat bulan, yakni dari bulan September sampai Desember 2020. Berdasarkan laporan Pusdatin Kemendikbud RI, bantuan kuota internet tahap I dan II pada September telah tersalurkan ke 27.305.495 nomor telepon seluler (ponsel) pendidik dan peserta didik di seluruh Indonesia.

Sebagai sebuah kebijakan publik tentu saja program subsidi kuota internet ini sempat menuai pro dan kontra di masyarakat. Akhir program bantuan kuota data Internet tahun 2020 ternyata Kemendikbud telah berhasil dan sukses melaksanakannya. Agenda pada tengah pandemi yang dibawah naungan dari Pusdatin Kemendikbud mengenai bantuan kuota internet gratis ternyata mendapat respon positif dari publik.
Pasca pihak Kemendikbud menerbitkan Peraturan Sekretaris Jenderal Nomor 14 Tahun 2020 tentang Petunjuk Teknis Bantuan Kuota Data Internet Tahun 2020 dan menjadi satu pedoman bagi penyaluran bantuan kuota data internet bagi pendidik dan peserta didik, ternyata hasilnya terhadap dunia pendidikan cukup memuaskan. Kebijakan bantuan kuota data internet yang diberikan bagi siswa, mahasiswa, pendidik dan guru, serta dosen telah berhasil dievaluasi secara menyeluruh meskipun harus melalui proses yang panjang sebelumnya.

Ada trend kenaikan penggunaan internet yang ternyata linier dengan situasi sekaligus kebijakan pemerintah Indonesia. Agenda dari Kemendikbud yang merealisasi bantuan kuota internet gratis bagi sekolah pada pembelajaran jarak jauh (PJJ) selama pandemi Covid-19 kini menuai hasil yang maksimal. Internet gratis dalam dunia pendidikan menjadi pintu utama untuk program selanjutnya.

Di tengah revoluasi industri 4.0, peran internet makin penting dalam kehidupan sosial, ekonomi dan politik dunia global. Keberadaan internet setiap tahun semakin mempengaruhi kehidupan umat manusia. Sehingga tidak bisa disangkal lagi bahwa teknologi internet telah merubah peradaban dunia dengan cepat seiring pusaran revoluasi industri 4.0. Laju perubahan semakin kencang membuat peradaban manusia mengalami evolusi kehidupan.

Bahkan, penggunaan internet seluruh dunia, baik yang mobile maupun yang fixed mengalami kenaikan secara terus menerus. Berdasarkan hasil pelaporan dari International Telecommunication Union (ITU) yang kini merupakan badan Perserikatan Bangsa- Bangsa (PBB), bahwa jumlah pengguna internet dunia 2018 sebesar 3,9 miliar melebihi setengah populasi dunia. Realitas tersebut merupakan hal fenomenal dalam perubahan peradaban yang mau tidak mau harus ikut berbaris menatap perubahan zaman.

Begitu pula tingkat kenaikan jumlah penggunaan internet dialami bangsa Indonesia. Hasil survei dari Asosiasi Penyelenggara Jasa Internet Indonesia (APJII) pada tahun 2018, jumlah pengguna internet di indonesia kini 
sebesar 171,1 juta, naik sebesar 27,9 juta dari tahun lalu yang berjumlah 143,2 juta. Bahkan diprediksi pada 2019 dan seterusnya juga akan mengalami trend kenaikan dikarenakan telah selesainya proyek jaringan palapa RING yang akan menambah keandalan koneksi internet di seluruh indonesia.

Hartanto (2016) mengungkapkan bahwa teknologi informasi dan telekomunikasi yang murah dan mudah akan menghilangkan batasan ruang dan waktu yang selama ini membatasi dunia pendidikan. Ada beberapa konsekuensi logis yang akan terjadi dalam penggunaan $e$ learning, antara lain (1) peserta didik dapat dengan mudah mengakses materi pembelajaran dimanapun tanpa terbatas lagi pada batasan tempat dan waktu; (2) peserta didik dapat dengan mudah berguru dan berdiskusi dengan para tenaga ahli atau pakar di bidang yang diminatinya; (3) materi pembelajaran bahkan dapat dengan mudah diambil di berbagai penjuru dunia tanpa tergantung pada dimana peserta didik belajar. Berbagai peluang tersebut masih menghadapi tantangan baik dari biaya, kesiapan infrastuktur teknologi informasi, masyarakat, dan peraturan yang mendukung terhadap kelangsungan e-learning.

Sehingga banyak sekali teknologi media pembelajaran yang berbentuk platform yang digunakan setiap instansi pendidikan, baik di tingkat sekolah maupun perguruan tinggi untuk mengefektifkan proses pembelajaran yang dilakukan. Seperti Google Classroom, Elearning, YouTube, WAG, Edmodo, Zoom, Googlemeet dan platform lainnya yang mampu menjadi penunjang fasilitas belajar dari rumah. Media pembelajaran disebut juga sebagai alat atau sumber belajar yang dapat membantu seorang guru dalam menyampaikan pesan kepada siswa (Yunanta, 2019).

Setiap platform yang digunakan tentu memiliki kekurangan serta kelebihan yang dimiliki pada saat digunakan untuk proses pembelajaran. Di dalam pelaksanaan proses pembelajaran daring perlu dilakukan evaluasi agar mendapatkan langkah perbaikan jelas yang berbasis data. Hal itulah yang mendasari penulis mengetahui gambaran penggunaan bantuan kuota internet Kemendikbud di masa pandemi.

\section{METODE}

Penelitian ini dilakukan melalui survei secara serentak. Agenda penelitian survei ini dimaksudkan sebagai alat untuk melakukan pengukuran dan mengetahui secara riil yang berdasarkan kepada pendekatan ilmiah tentang sejauhmana persepsi publik dan tingkat kepuasan publik (approval rating) terhadap program subsidi kuota internet yang sudah dilakukan sejauh ini. Dalam konteks pemerintahan, survei berfungsi sebagai bahan evaluasi: mengukur tingkat efisiensi suatu kebijakan, mengukur dampak suatu kebijakan, dan tentu saja sebagai masukan (input) suatu kebijakan yang akan datang.

Adapun wilayah dari pelaksanaan survei ini sebanyak 34 provinsi di Indonesia. Metode penarikan sampel menggunakan Multistage Random Sampling dengan jumlah responden sebanyak 1000 responden dengan margin of error $+/-3.10 \%$ pada tingkat kepercayaan $95 \%$. Agenda survei tersebut dilakukan dengan cara telesurvei, yaitu responden yang diwawancara peneliti melalui kontak telepon menggunakan kuesioner. Sehingga kendali mutu survei ada pada pewawancara yang minimal mahasiswa atau sederajat dan mendapatkan pelatihan (workshop) secara intensif setiap pelaksanaan survei. Validasi data sampel dilakukan dengan membandingkan karakteristik demografis dari sampel diperoleh dari survei dengan populasi yang diperoleh melalui data sensus (BPS) terakhir.

Survei menggunakan teknik multistage random sampling dengan populasi desa atau kelurahan tingkat nasional. Desa/kelurahan di Indonesia juga dipilih secara random dengan jumlah proporsional. Di setiap desa/kelurahan terpilih, dipilih sebanyak 5 (lima) RT dengan cara random. Masing-masing daripada RT atau lingkungan terpilih, dipilih secara random 2 (dua) KK. Di setiap KK terpilih, dipilih secara random 1 (satu) orang dewasa (memiliki hak pilih) laki-laki atau perempuan.

Adapun quality control terhadap hasil survei dilakukan melalui cara Callback dan 
Spotchek, dimana sebanyak 25 persen dari total responden akan dikontak kembali guna keperluan konfirmasi dan verifikasi. Langkah selanjutnya adalah proses input data, dimana quality control juga dilakukan terhadap proses input data, sebanyak 30\% dicek secara acak input data ke dokumen hasil wawancara untuk mengetahui konsistensi jawaban yang pasti pada kuisioner.

\section{HASIL DAN PEMBAHASAN Hasil}

Keputusan pemerintah meliburkan para peserta didik dan memindahkan proses belajar mengajar di sekolah menjadi di rumah dengan menerapkan kebijakan baru Work From Home (WFH) membuat resah banyak pihak. WFH adalah singkatan dari work from home yang berarti bekerja dari rumah. Kebijakan WFH ada di Surat Edaran Menteri Pendayagunaan Aparatur Negara dan Reformasi Birokrasi (PAN \& RB) Nomor 50/2020 tentang Perubahan Kedua atas Surat Edaran Menteri PAN \& RB Nomor 19/2020 tentang Penyesuaian Sistem Kerja Aparatur Sipil Negara dalam Upaya Pencegahan Penyebaran Covid-19 di Lingkungan Instansi Pemerintah.

Sebagai ASN, dosen, guru, mahasiswa dan siswa dalam melaksanakan proses belajar mengajar perlu dilakukan secara online atau dalam jaringan (daring). Namun, pelaksanaan proses pembelajaran secara online memiliki beberapa kendala, dimana salah satu kendala terberat dalam pembelajaran daring adalah sisi biaya internet yang mulai terasa. Hal ini yang membuat pemerintah membuat program untuk bantuan kuota internet gratis.

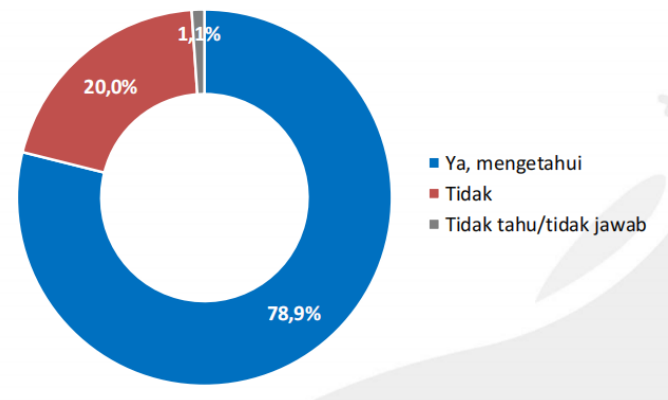

Gambar 1. Pengetahuan terhadap Program

Bantuan Kuota Internet Gratis Kemendikbud
Dalam survei yang dilakukan, peneliti bertanya tentang apakah bapak/ibu/saudara mengetahui program bantuan kuota internet gratis dari Kemendikbud RI? Hasil jawaban survei menyebutkan bahwa sebanyak 78,9\% publik ternyata mengetahui program bantuan internet gratis Kemendikbud RI. Sementara itu, sekitar 20,0\% jawaban survei menjawab tidak tahu dan sisanya hanya $1,1 \%$ yang mengaku tidak tahu/tidak jawab. Pemahaman terhadap program bantuan kuota internet gratis sudah di pahami publik atas langkah dari pemerintah merespon kebutuhan dan beban pulsa atau kuota untuk proses pembelajaran di tanah air.

Dalam implementasinya, bantuan kuota gratis internet mampu meringankan beban saat proses pembelajaran. Pemberian kuota internet dari pemerintah mampu mengatasi beban atas kebutuhan kuota internet yang diperlukan bagi kalangan pendidikan. Distribusi kuota secara berjenjang dalam pendidikan membuat proses kegiatan belajar mengajar menjadi lancar dan beban kuota internet menjadi ringan.

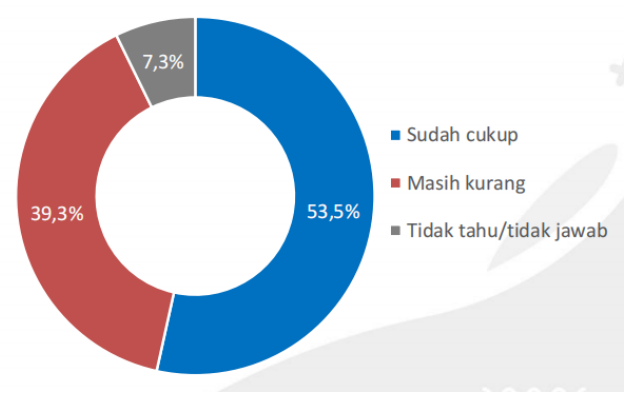

Gambar 2. Kecukupan Bantuan Kuota Internet Gratis Kemendikbud

Adapun pembagian kuota internet gratis Kemendikbud dilakukan secara berjenjang. Dari data yang ada diketahui bahwa peserta didik PAUD mendapatkan 20 GB per bulan, peserta didik jenjang pendidikan dasar dan menengah mendapatkan 35 GB per bulan, pendidik PAUD dan jenjang pendidikan dasar dan menengah mendapatkan 42 GB per bulan, dan mahasiswa dan dosen mendapatkan $50 \mathrm{~GB}$ per bulan.

Peneliti menanyakan apakah menurut pendapat bapak/ibu/saudara bahwa apa jumlah kapasitas kuota internet (GB) tersebut sudah 
cukup? Dari pertanyaan tersebut, sebanyak 53,5\% publik mengaku sudah cukup dengan jumlah dari kapasitas kuota internet tersebut. Sementara itu sebanyak 39,3\% mengaku masih kurang dan sisanya ada 7,3\% yang mengaku tidak tahu atau tidak jawab.

Kebijakan pemerintah dalam merespon kebutuhan kuota internet bagi kegiatan belajar mengajar di tengah pandemi, tentu ada kurang lebihnya. Publik merespon kebijakan bantuan kuota internet gratis dalam memenuhi pribadi guna membantu dalam proses kegiatan belajar mengajar. Ketercukupan maupun tidaknya atas bantuan kuota internet gratis menjadi sesuatu hal yang perlu untuk dicari tahu kebenarannya.

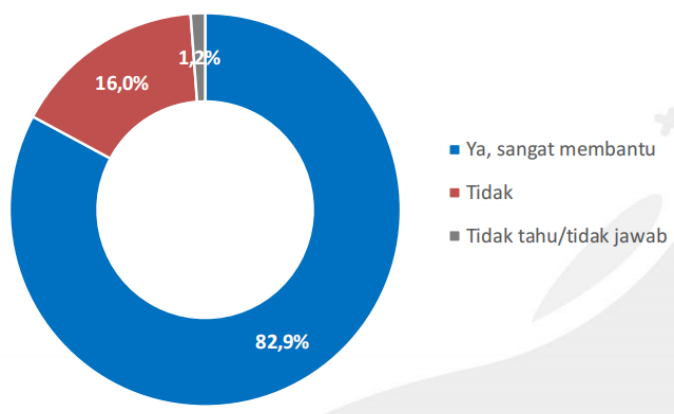

Gambar 3. Keterbantuan Kuota Internet Gratis Kemendikbud

Peneliti kemudian menanyakan menurut pendapat bapak/ibu/saudara apa program kuota internet gratis sangat membantu proses belajar mengajar selama masa pandemi Covid-19? Dari pertanyaan tersebut, ternyata sebanyak $82,9 \%$ responden atau publik menilai bahwa program bantuan kuota internet gratis sangat membantu proses belajar mengajar selama masa pandemi Covid-19. Sementara sebanyak 16,0\% menjawab tidak membantu pada proses belajar mengajar dan sisanya $1,2 \%$ mengaku tidak tahu/tidak jawab.

Keterbantuan kalangan pendidikan atas bantuan kuota internet gratis di proses belajar mengajar sangat beragam. Penggunaan atas bantuan kuota internet gratis juga beragam dan tergantung pada waktu tertentu. Pada masingmasing kalangan memiliki tingkat intensitas penggunaan bantuan kuota gratis internet dari Kemendikbud.

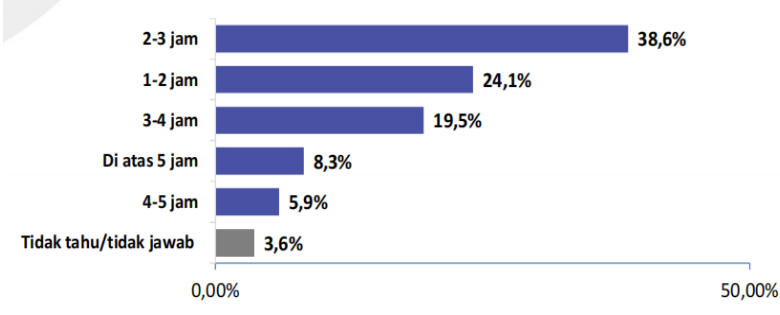

Gambar 4. Penggunaan Waktu Kuota Internet Gratis Kemendikbud

Peneliti kemudian menanyakan menurut pendapat bapak/ibu/saudara mengenai berapa jam dalam sehari memanfaatkan kuota internet untuk belajar? Pertanyaan yang disampaikan bagi yang mendapat program bantuan kuota gratis internet, ternyata memperoleh jawaban publik saat memanfaatkan kuota internet untuk belajar 2-3 jam sebanyak 38,6\%, disusul 1-2 jam (24,1\%), 3-4 jam (19,5\%), di atas 5 jam (8,3\%), dan 4-5 jam (5,9\%). Pemanfaatan berapa jam dalam sehari pada kuota internet untuk belajar sebanyak 3,6 \% yang mengaku tidak tahu/tidak jawab.

Pemanfaatan atas bantuan kuota gratis internet sesungguhnya bisa digunakan untuk umum dan khusus belajar. Masing-masing bantuan kuota internet memiliki nilai besaran kuota. Besaran bantuan kuota gratis internet sangat berpengaruh terhadap sisi penggunaan kesehariannya.

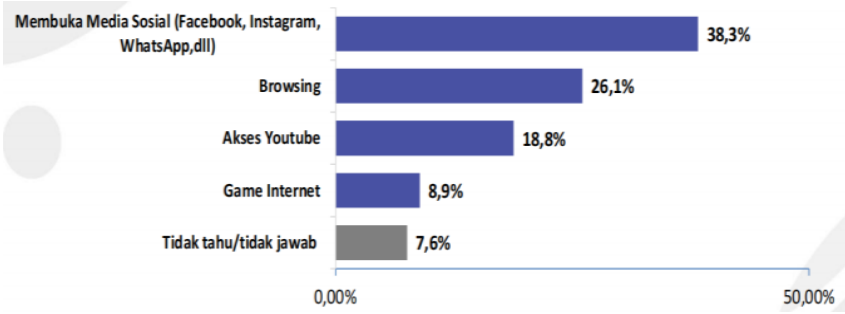

Gambar 5. Penggunaan Kuota Umum Internet Gratis Kemendikbud

Dalam program bantuan kuota internet, ada kuota untuk belajar dan ada kuota untuk umum. Peneliti menanyakan menurut pendapat bapak/ibu/saudara mengenai kuota internet umum biasanya dipergunakan untuk apa? Dari pertanyaan tersebut, respon publik bahwa memanfaatkan kuota internet umum untuk membuka media sosial sebanyak $38,3 \%$. Lalu, disusul pemanfaatan untuk browsing $(26,1 \%)$, 
akses Youtube $(18,8 \%)$, dan game internet $(8,9 \%)$. Sisanya sebanyak $7,6 \%$ yang mengaku tidak tahu atau tidak jawab atas penggunaan bantuan kuota gratis internet untuk umum.

Di samping penggunaan bantuan kuota gratis untuk umum, kuota yang ada untuk proses belajar mengajar. Pada pembelajaran daring, terdapat berbagai platform belajar yang dapat diakses melalui bantuan kuota gratis internet. Berbagai macam dari platform belajar internet mempunyai tingkat intensitas berbeda atau ritme penggunaan oleh publik berbedabeda.

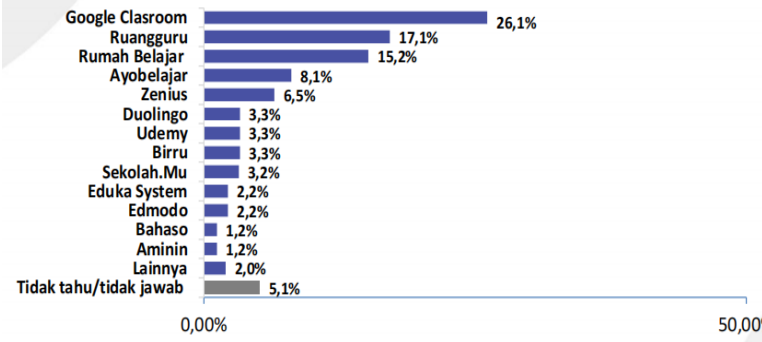

Gambar 6. Penggunaan Platform Belajar Kuota Internet Gratis Kemendikbud

Di antara platform belajar yang ada saat ini, peneliti menanyakan bapak/ibu/saudara terhadap platform belajar mana yang sering dipergunakan? Dari hasil pertanyaan tersebut, publik mengaku sering menggunakan platform belajar Google Clasroom sebanyak 26,1\% dan disusul Ruangguru (17,1\%). Selanjutnya, penggunaan Rumah Belajar (15,2\%), di susul Ayobelajar (8,1\%), Zenius (6,5\%), Duolingo (3,3\%), Udemy (3,3\%), Birru (3,3\%), Sekolah.Mu (3,2\%), Eduda System (2,2\%), Edmodo (2,2\%), Bahaso (1,2\%), Aminin $(1,2 \%)$, dan lainnya $(2,0 \%)$. Sisanya $5,1 \%$ yang mengaku tidak tahu/tidak jawab atas penggunaan platform belajar.

Selain penggunaan bantuan kuota gratis internet untuk platform belajar, juga digunakan lainnya. Salah satunya juga bisa dipergunakan untuk Video Call pada kuota internet gratis dari bantuan Kemendikbud.

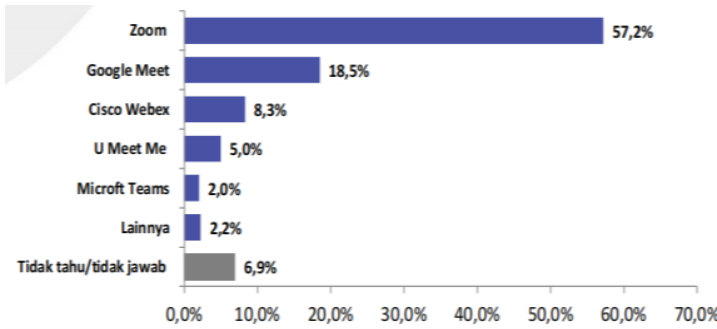

Gambar 7. Penggunaan Video Call pada Kuota Internet Gratis Kemendikbud

Di antara media video call yang ada saat ini, peneliti menanyakan ke bapak/ibu/saudara seringnya penggunaannya dalam pembelajaran daring? Dari pertanyaan yang ada, responden menjawab penggunaan media video call dalam pembelajaran daring, ternyata dari mayoritas publik menggunakan aplikasi Zoom (57,2\%), disusul Google Meet (18,5\%), Cisco Webex (8,3\%), U Meet Me (5,0\%), Microsoft Teams $(2,0 \%)$, dan lainnya $(2,2 \%)$. Dari pertanyaan yang ada, sisanya sebanyak $6,9 \%$ mengaku tidak tahu/tidak jawab tentang penggunaan video call tersebut.

Dari setiap penggunaan media yang kini dipergunakan tentu memiliki kekurangan serta kelebihan yang dimiliki pada saat digunakan untuk proses pembelajaran. Masing-masing juga memiliki celah untuk ditingkatkan secara maksimal dalam penggunaan pada saat proses belajar mengajar. Realitas ini tentunya menjadi tantangan bagi pengguna media pembelajaran daring saat ini.

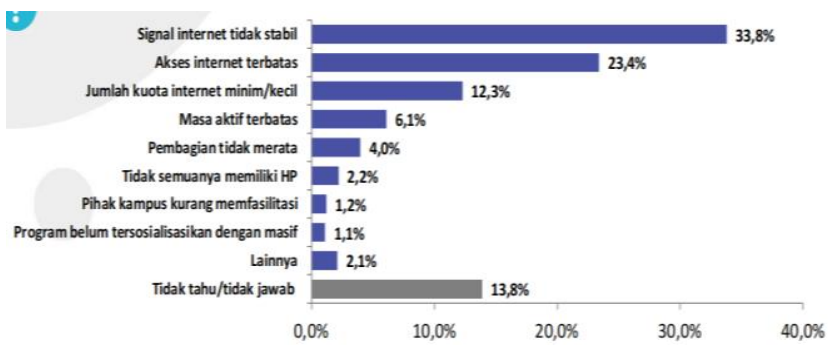

Gambar 8. Kendala Penggunaan Kuota Internet Gratis Kemendikbud

Peneliti menanyakan menurut pendapat bapak/ibu/saudara mengenai apa yang menjadi kendala utama dari program bantuan kuota internet ini? Dari pertanyaan tersebut, publik mengaku bahwa yang menjadi kendala utama program bantuan kuota internet adalah "Signal internet tidak stabil" sebanyak 33,8\%, disusul 
akses internet terbatas $(23,4 \%)$, jumlah kuota internet $\mathrm{minim} / \mathrm{kecil}(12,3 \%)$, masa aktif terbatas $(6,1 \%)$, pembagian tidak merata $(4,0 \%)$, tidak semuanya memiliki HP (2,1\%), pihak kampus kurang memfasilitasi $(1,2 \%)$, program belum tersosialisasikan dengan masif $(1,1 \%)$, dan lainnya $(2,1 \%)$. Sisanya sebanyak $13,8 \%$ yang mengaku tidak tahu/tidak jawab atas pertanyaan yang menjadi kendala utama program bantuan kuota gratis internet.

\section{Pembahasan}

Berdasarkan data tersampaikan di atas, maka pembahasan sebagai berikut:

\section{Pengetahuan Bantuan Kuota Internet}

Hasil survei yang menyebutkan sebanyak $78,9 \%$ publik mengetahui program bantuan internet gratis Kemendikbud menjadi satu bukti keberhasilan sosialisasi kebijakan pemerintah. Pertanyaan survei mengenai pengetahuan kebijakan program bantuan kuota internet gratis dari Kemendikbud menunjukkan pemahaman publik terhadap langkah pemerintah merespon kebutuhan dan beban pulsa atau kuota untuk proses pembelajaran di tanah air.

Menurut pendapat Hendrastomo (2008) bahwa ketersediaan akses internet sangat diperlukan dalam pembelajaran e-learning, karena karakteristik pembelajaran ini selalu menggunakan dan memanfaatkan jaringan internet. Secara umum, kecepatan akses jaringan internet di Indonesia relatif lambat, ketersediaan jaringan internet yang masih terbatas dan harga untuk mengakses internet relatif mahal sehingga menjadi hambatan bagi pembelajaran e-learning. Penggunaan media online dalam pembelajaran daring memungkinkan peserta didik untuk memiliki semangat yang tinggi untuk belajar dan mengerjakan tugas.

Respon publik terhadap kebijakan bantuan kuota gratis internet karena memang dari sisi kebutuhan sangat signifikan. Hasil dari penelitian Sianturi (2018) menunjukkan bahwa penggunaan internet pada mahasiswa secara signifikan dapat memengaruhi motivasi mahasiswa dalam menggunakan $e$ learning. Hasil penelitian Puspitasari dkk.
(2018) menunjukkan memang terdapat satu pengaruh sangat signifikan di penggunaan media pembelajaran terhadap motivasi peserta didik. Kebutuhan terhadap kuota internet mempengaruhi penggunaan media pembelajaran supaya berjalan dengan lancar dan baik.

Sementara itu, sekitar 20,0\% jawaban survei menjawab tidak tahu dan hanya $1,1 \%$ yang mengaku tidak tahu atau tidak jawab karena tidak menggunakan kuota internet dalam proses belajar mengajar. Stagnasi belajar bisa terjadi pada proses belajar mengajar atau memang daerah yang tidak terkena dampak pandemi, sehingga proses belajar mengajar masih konvensional dan tatap muka.

\section{Kecukupan Bantuan Kuota Internet}

Data pembagian kuota internet gratis dari Kemendikbud dilakukan secara berjenjang. Program bantuan kuota gratis internet dari data yang ada diketahui untuk peserta didik PAUD mendapatkan 20 GB per bulan, bagi peserta didik jenjang pendidikan dasar dan menengah mendapatkan 35 GB per bulan. Sedangkan, bantuan kuota gratis internet bagi pendidik PAUD, jenjang pendidikan dasar dan menengah mendapatkan 42 GB per bulan. Sedangkan bantuan kuota gratis bagi mahasiswa dan dosen mendapatkan $50 \mathrm{~GB}$ per bulan.

Hasil pertanyaan menyebutkan sebanyak 53,5\% publik mengaku sudah cukup dengan jumlah dari kapasitas kuota internet. Imbas pandemi virus corona membuat semua negara berpikir untuk melakukan interaksi dan kegiatan pembelajaran yang efektif. Salah satu caranya melakukan kegiatan dalam jaringan (daring) rumah masingmasing (Wicaksono dan Rachmadyanti, 2016). Kecukupan bantuan kuota internet yang diberi langsung dapat terimplementasi dalam proses kegiatan belajar mengajar. Hal ini dapat ditunjukkan pada keberlangsungan proses belajar mengajar secara daring. Proses pembelajaran daring yang terus berlangsung selama periode hampir setahun berlalu, kegiatan belajar mengajar masih terus berlangsung tanpa muncul persoalan yang signifikan. 
Bila keberhasilan kegiatan belajar mengajar ditentukan oleh media pembelajaran dan cara penyampaian yang mudah dipahami. Apabila dalam praktik mengajar secara daring seorang dosen tidak mampu mengoptimalisasikan media dan teknologi yang ada, maka capaian pembelajaran dapat tidak tercapai (Saddhono, 2015).

Sehingga guru dan murid atau dosen dan mahasiswa mencari jalan sendiri bagaimana membangun efektifitas belajar dan saling memberikan ruang nyaman satu sama lain. Pemberian bantuan kuota internet gratis menjadi sarana atau modal cukup untuk bisa diimplementasikan secara maksimal dalam proses belajar mengajar. Sebaliknya, adanya sebanyak 39,3\% yang mengaku masih kurang dan ada 7,3\% yang mengaku tidak tahu atau tidak jawab merupakan bentuk tak bisa melakukan manajemen di pengelolaan bantuan kuota internet.

\section{Keterbantuan Kuota Internet}

Berdasarkan data bahwa program kuota internet gratis sangat membantu proses belajar mengajar selama masa pandemi Covid-19 sebanyak 82,9\% responden atau publik yang menilai tentu harus dipahami secara signifikan. Program bantuan kuota internet gratis memang sangat membantu proses belajar mengajar selama masa pandemi Covid-19.

Adanya pandemi Covid-19 melanda seluruh negeri di belahan dunia termasuk Indonesia. Salah satu cara untuk memutus mata rantai penyebaran Covid-19 dengan melakukan pembatasan interaksi masyarakat yang sudah diterapkan dengan istilah physical distancing. Kebijakan physical distancing diharapkan menghambat laju pertumbuhan dalam berbagai bidang kehidupan, baik bidang ekonomi, sosial, dan tentu saja pendidikan. Keputusan pemerintah untuk meliburkan peserta didik, memindahkan proses belajar mengajar di sekolah menjadi di rumah dengan menerapkan kebijakan Work From Home (WFH) awalnya memang membuat resah banyak pihak.

Sehingga untuk melaksanakan proses dari pembelajaran perlu dilakukan secara online atau dalam jaringan (daring). Pelaksanaan proses pembelajaran secara online memiliki beberapa kendala. Penggunaan media online atau media berbasis multimedia merupakan salah satu solusi untuk membuat peserta didik mampu memahami materi pelajaran dengan baik.

Pembelajaran dilakukan dengan manfaatkan teknologi informasi dan komunikasi yang tergantung pada peran pengajar sebagai fasilitastor bukan hanya sebagai pemberi informasi saja, tetapi juga memberikan kemudahan dalam pembelajaran (Hanum, 2013).

Kemudahan yang diperoleh dalam proses belajar mengajar secara daring tentu lebih terbantukan saat pemerintah memfasilitasi melalui bantuan kuota internet gratis. Dari sistem yang terbangun pada akhirnya dapat berjalan maksimal tatkala dukungan kuota gratis internet, sehingga proses kegiatan belajar mengajar dapat berlangsung secara maksimal.

Sebaliknya, data publik yang menyebutkan sebanyak $16,0 \%$ menjawab tidak membantu pada proses belajar mengajar dan sisanya $1,2 \%$ mengaku tidak tahu atau tidak jawab karena sama sekali tak menggunakan media pembelajaran secara daring. Hal ini bisa saja terjadi mengingat ada wilayah yang tidak memiliki jangkauan internet atau tidak terkena imbas dari pandemi.

\section{Penggunaan Waktu Kuota Internet}

Dari data penggunaan mengenai berapa jam dalam sehari memanfaatkan kuota internet untuk belajar terdeteksi. Bahwa penerima program bantuan kuota gratis internet, ternyata memperoleh jawaban publik saat memanfaatkan kuota internet untuk belajar 2-3 jam sebanyak 38,6\%, disusul 1-2 jam $(24,1 \%), 3-4$ jam $(19,5 \%)$, di atas 5 jam $(8,3 \%)$, dan $4-5$ jam $(5,9 \%)$.

Dalam proses belajar dan mengajar yang dilakukan dengan cara memanfaatkan dan menggunakan sebuah teknologi informasi dan komunikasi merupakan salah satu bimbingan dari pengajar untuk senantiasa memfasilitasi pembelajaran yang efektif bagi 
pembelajar dalam melakukan pembelajaran dimasa pandemi Covid-19 (Munir, 2009).

Dengan adanya teknologi internet, maka orang yang berada di negara lain dapat melihat orang lainnya untuk berkomunikasi (Setyawati, 2016). Sebagai suatu bentuk alat komunikasi, media menjadi penunjang keberhasilan dalam kegiatan pembelajaran. Salah satu bukti nyata adalah penggunaan media digital, seperti audio, visual, dan audio-visual (Putri dkk., 2019).

Intensitas penggunaan media pembelajaran daring menjadi kebiasaan pasca pandemi selain mulai terbiasa dengan kenyamanan dalam bekerja dari rumah. Pemanfaatan bantuan kuota internet dalam pembelajaran akan bervarian sesuai dengan kebutuhan dan produktivitas kerja secara pribadi. Era pandemi saat ini, bantuan kuota internet gratis dapat dimanfaatkan secara maksimal dalam kegiatan belajar mengajar.

Sebaliknya, minimnya pemanfaatan jam terhadap bantuan kuota internet untuk belajar sebanyak 3,6 \% yang mengaku tidak tahu atau tidak jawab barangkali terbatasnya sinyal atau memang daerah tidak terdampak pandemi. Fenomena daerah susah sinyak dan tak terdampak pandemi sangat mungkin terjadi karena aspek geografis Indonesia terdiri dari ribuan pulau hingga mencapai pelosok.

\section{Kuota Umum Bantuan Internet}

Dalam program bantuan kuota internet, ada kuota untuk belajar dan ada kuota untuk umum. Saat peneliti menanyakan mengenai kuota internet umum biasanya dipergunakan untuk apa, ternyata respon atau publik telah memanfaatkan kuota internet umum untuk membuka media sosial sebanyak 38,3\%. Lalu, disusul pemanfaatan untuk browsing $(26,1 \%)$, akses Youtube $(18,8 \%)$, dan game internet $(8,9 \%)$.

Keberadaan teknologi didefinisikan sebagai suatu bentuk pemutakhiran di dalam bidang ilmu pengetahuan. Kemunculan teknologi membuat tugas manusia menjadi lebih mudah dan cepat (Fauzi dan Tambunan, 2016). Saat ini, siapapun dapat menjalin komunikasi lintas daerah, lintas wilayah atau lintas negara. Media sosial tanpa batas telah melampaui dinding-dinding dan sekat yang ada saat ini. Bantuan kuota internet gratis untuk kuota umum dimanfaatkan bagi kalangan pendidikan sebagai fasilitas media sosial gratis. Di tengah kepenatan akibat impas pandemi yang harus mau mengurangi interaksi secara langsung, media sosial jadi ruang publik yang dimanfaatkan maksimal kalangan pendidikan.

Relasi antara teknologi dan komunikasi yang terbangun di tengah pandemi semakin kuat karena terbatasnya interaksi. Hal ini juga bentuk perkembangan teknologi yang cepat pasca pandemi. Dimana salah satu penunjang dalam perkembangan teknologi adalah penggunaan internet. Keduanya saling berkaitan erat dan mendukung untuk bekerja, berkomunikasi, dan melakukan pembangunan zaman (Alia dan Irwansyah, 2018).

Selain itu, bahwa kemajuan dalam bidang teknologi menjadi bukti kemajuan suatu bangsa. Salah satu pendukung teknologi semakin berkembang adalah penggunaan internet. Internet menjadi media komunikasi antar masyarakat, antar wilayah dan bahkan antar bangsa menjadi semakin mudah dan cepat. Hal ini membuat internet menjadi kebutuhan wajib untuk masyarakat dunia saat pandemi virus corona (Gumgum dkk., 2017).

Tingginya tingkat berselancar media sosial menunjukkan bahwa pengguna bantuan kuota internet ingin memaksimalkan dalam hal penggunaan. Sebaliknya, sisa sebanyak $7,6 \%$ yang mengaku tidak tahu atau tidak jawab atas penggunaan bantuan kuota gratis internet untuk umum dikarenakan faktor keterbatasan sinyal, lokasi terpelosok dan tidak mempunyai fasilitas android ataupun handphone memadai dalam penggunaan internet.

\section{Platform Belajar Bantuan Kuota Internet}

Pada data tentang platform belajar yang ada saat ini, ternyata hanya platform belajar tertentu yang sering dipergunakan. Data dari hasil pertanyaan publik mengaku sering menggunakan platform belajar Google 
Clasroom sebanyak 26,1\% dan disusul platform Ruangguru $(17,1 \%)$. Selanjutnya, penggunaan Rumah Belajar (15,2\%), di susul Ayobelajar $(8,1 \%)$, Zenius $(6,5 \%)$, Duolingo (3,3\%), Udemy (3,3\%), Birru (3,3\%), Sekolah.Mu (3,2\%), Eduda System (2,2\%), Edmodo (2,2\%), Bahaso (1,2\%), Aminin (1,2\%), dan lainnya (2,0\%).

Banyak teknologi media pembelajaran yang berbentuk platform yang digunakan disetiap instansi pendidikan, pada tingkat sekolah maupun di perguruan tinggi untuk bisa mengefektifkan proses pembelajaran yang dilakukan. Seperti Google Classroom, Elearning, YouTube, WAG, Edmodo, Zoom, Googlemeet dan platform lainnya yang mampu menjadi penunjang fasilitas belajar dari rumah. Media pembelajaran disebut juga sebagai alat atau sumber belajar yang dapat membantu seorang guru dalam menyampaikan pesan kepada siswa (Yunanta, 2019).

Setiap platform yang ada dan digunakan tentu memiliki kekurangan serta kelebihan yang dimiliki pada saat digunakan untuk proses pembelajaran. Pada masa pandemi seperti sekarang ini, belajar dari rumah atau belajar secara jarak jauh menjadi jalan utama agar pembelajaran tetap berlangsung dengan baik dan efektif. Akan tetapi pembelajaran dilaksanakan dengan cara online atau daring dengan menggunakan teknologi sekarang yang semakin canggih yang dapat digunakan untuk menunjang proses pembelajaran dimasa pandemi sekarang ini. Dalam hal ini, sisi jaringan internet menjadi hal yang paling penting dalam proses pembelajaran yang dilakukan karena tanpa ada jaringan internet peserta didik tidak dapat mengakses platform tersebut untuk melakukan pembelajaran.

Data dari sisanya $5,1 \%$ yang mengaku tidak tahu/tidak jawab atas penggunaan platform belajar bukan berarti tidak menggunakan pembelajaran daring. Bisa juga tidak mau menggunakan karena memakai aplikasi lain. Di samping itu, minimnya sinyal karena ada pada wilayah terpelosok dan susah sinyal, sehingga tidak bisa menggunakan teknologi pembelajaran.

\section{Video Call Bantuan Kuota Internet}

Data yang menyebutkan bahwa media video call yang seringkali dipergunakan dalam pembelajaran daring terhadap bantuan kuota internet gratis telah terjawab. Bahwa dari responden menjawab tentang penggunaan media video call dalam pembelajaran daring, ternyata mayoritas publik menggunakan aplikasi Zoom (57,2\%), disusul Google Meet $(18,5 \%)$, Cisco Webex $(8,3 \%)$, U Meet Me (5,0\%), Microsoft Teams (2,0\%), dan lainnya $(2,2 \%)$.

Penggunaan aplikasi komunikasi dua arah sangat efektif dalam kegiatan pembelajaran. Hal ini dibuktikan dengan peningkatan nilai yang mencapai standardisasi kelulusan. Penggunaan Google class efektif digunakan untuk komunikasi satu arah dengan mahasiswa, seperti pemberian materi dan tugas. Akan tetapi, untuk diskusi dan tanya jawab penggunaan teknologi seperti Zoom, Google Hangouts ternyata dapat membuat komunikasi juga semakin interaktif. Tujuan pembelajaran dapat tercapai dengan baik, meski kegiatan belajar-mengajar dilakukan secara daring. (Hudaa dkk., 2020). Selain itu, tujuannya juga memutus penyebaran virus corona yang ada di Indonesia. Beberapa media sudah tersedia, seperti Google Kelas, Google Hangouts, Zoom dan aplikasi lainnya (Chaeruman, 2017).

Harus dipahami karena adanya pandemic covid-19 yang penularannya secara cepat melalui kontak langsung dengan penderita, maka di larang mengadakan perkumpulan. Dunia pendidikan juga kena imbas, maka pembelajaran dilakukan secara daring, sehingga ada beberapa media pembelajaran online yang bisa dijadikan pilihan. Berdasarkan hal di atas melihat situasi dan kondisi pada masa pandemic covid-19 guru atau dosen harus cerdas memilih media pembelajaran yang harus digunakan dalam proses pembelajaran agar tidak ketinggalan materi. Sehingga para pendidik diharuskan menguasai banyak media pembelajaran.

Sebaliknya, jawaban atas pertanyaan yang ada, dimana sisa sebanyak 6,9\% mengaku tidak tahu/tidak jawab tentang penggunaan 
video call harus dicermati. Faktor wilayah yang minim sinyal dan keterbatasan sarana prasarana menjadi faktor maksimal tidaknya pemakaian bantuan kuota internet gratis.

\section{Kendala Program Bantuan Kuota Internet}

Data terhadap kendala utama dari program bantuan kuota internet patut dikaji secara seksama. Dari pertanyaan, publik mengaku bahwa kendala utama dari program bantuan kuota internet adalah "Signal internet tidak stabil" sebanyak $33,8 \%$, disusul akses internet terbatas $(23,4 \%)$, jumlah kuota internet $\mathrm{minim} / \mathrm{kecil}(12,3 \%)$, masa aktif terbatas $(6,1 \%)$, pembagian tidak merata $(4,0 \%)$, tidak semuanya memiliki HP $(2,1 \%)$, pihak kampus kurang memfasilitasi $(1,2 \%)$, program belum tersosialisasikan dengan masif $(1,1 \%)$, dan lainnya $(2,1 \%)$.

Waryanto (2006) mengungkapkan bahwa keuntungan dari model pembelajaran daring dapat digunakan untuk menyampaikan pembelajaran tanpa dibatasi ruang dan waktu, dapat menggunakan berbagai sumber yang sudah tersedia di internet, dan bahan ajar relatif mudah untuk diperbaharui. Selain itu, dapat meningkatkan kemandirian peserta didik dalam proses pembelajaran.

Kendala yang terjadi dilapangan tentu harus menjadi perhatian bagi pemerintah. Proses pembelajaran tidak akan terwujud apabila kendala lapangan belum teratasi. Persoalanpersoalan lapangan harus diselesaikan lebih dahulu agar proses belajar mengajar daring bisa terwujud. Apabila proses daring dapat terwujud, baru masuk pada langkah inovasi pembelajaran supaya pembelajaran lebih baik, inovatif dan tidak membosankan.

Hal ini sebagaimana penelitian Chandrawati (2010) bahwa pengajar diharapkan dapat menyajikan materi melalui web yang menarik dan diminati, melayani bimbingan dan komunikasi melalui internet, dan kecakapan lain yang diperlukan. Hal ini bisa terwujud apabila persoalan teknis kendala lapangan terhadap bantuan kuota internet gratis sudah terselesaikan. Sebaliknya, sisa sebanyak $13,8 \%$ yang mengaku tidak tahu atau tidak jawab pertanyaan yang menjadi kendala utama program bantuan kuota gratis internet barangkali sudah pada zona nyaman dalam setiap operasionalisasi penggunaan media pembelajaran daring.

\section{PENUTUP}

Kebijakan daripada program Pusdatin Kemendikbud RI atas bantuan kuota internet gratis mendapat respon positif dari publik. Dari data survei menunjukkan sebanyak $84,7 \%$ publik menilai program bantuan internet gratis merupakan langkah tepat menjawab sense of crisis di tengah wabah corona (Covid-19), sementara $13,7 \%$ tidak dan tersisa hanya $1,6 \%$ mengaku tidak tahu/tidak jawab.

Sementara itu, sebanyak $85,6 \%$ publik menilai bahwa program bantuan internet gratis meringankan beban ekonomi orang tua pelajar atau mahasiswa dalam membeli paket internet, sementara $13,6 \%$ tidak dan sisanya ada $0,8 \%$ mengaku tidak tahu/tidak jawab. Selanjutnya, ada sebanyak $63,2 \%$ publik mengaku puas (sangat puas \& cukup puas) dengan kinerja Pusdatin Kemendikbud RI dalam menyalurkan bantuan kuota internet, sementara 32,1\% mengaku tidak puas (kurang puas \& sangat tidak puas) serta sisanya $4,7 \%$ mengaku tidak tahu/tidak jawab.

Adapun terkait platform belajar yang paling sering digunakan mulai dari platform Google Clasroom (26,1\%), Ruangguru (17,1\%) dan Rumah Belajar $(15,2 \%)$ menempati posisi tiga besar. Lalu, disusul kemudian Ayobelajar $(8,1 \%)$, Zenius (6,5\%), Duolingo (3,3\%), Udemy (3,3\%), Birru (3,3\%), Sekolah.Mu (3,2\%), Eduda System (2,2\%), Edmodo (2,2\%), Bahaso (1,2\%), Aminin (1,2\%), dan lainnya 2,0\% serta sisanya $5,1 \%$ mengaku tidak tahu atau tidak jawab.

Untuk penggunaan media video call dalam pembelajaran daring, mayoritas publik menggunakan aplikasi Zoom (57,2\%), disusul Google Meet (18,5\%), Cisco Webex (8,3\%), U Meet Me (5,0\%), Microsoft Teams (2,0\%), dan lainnya $(2,2 \%)$ serta tersisa $6,9 \%$ mengaku tidak tahu/tidak jawab. Adapun masukan dari publik terkait program kuota internet gratis antara lain yakni: memperbaiki signal internet tidak stabil $(23,8 \%)$, askes internet yang terbatas $(16,0 \%)$, pembagian bantuan yang 
harus lebih merata (13,3\%), jumlah kuota internet minim/kecil $(9,3 \%)$, perlu pengawasan $(5,1 \%)$, dan lainnya.

\section{DAFTAR PUSTAKA}

Alia, T., \& Irwansyah. (2018). Pendampingan Orang Tua pada Anak Usia Dini dalam Penggunaan Teknologi Digital. A Journal of Language, Literature, Culture and Education. https://doi.org/10.19166/pji.v14i1.639

Chandrawati, S. R. (2010). Pemanfaatan elearning dalam pembelajaran. Jurnal Cakrawala Pendidikan, 8(2), 172-181.

Chaeruman, U. A. (2017). Pedati Model Desain Sistem Pembelajaran Blended. Direktorat Pembelajaran dan Kemahasiswaan Kemristekdikti.

Fauzi, I., \& Tambunan, H. (2016). Teknologi Pendidikan. In Pola-pola Pembelajaran. https://doi.org/10.1046/j.10958649.2003.00240.x

Gumgum, G., Justito, A., \& Nunik, M. (2017). Literasi Media: Cerdas Menggunakan Media Sosial Dalam Menanggulangi Berita Palsu (Hoax) Oleh Siswa Sma. Pengabdian Kepada Masyarakat. https://doi.org/1410 - 5675

Hanum, N. S. (2013). Keefektifan E-learning Sebagai Media Pembelajaran. Jurnal Pendidikan Vokasi, 92.

Hartanto, W. (2016). Penggunaan E-Learning sebagai Media Pembelajaran. Jurnal Pendidikan Ekonomi, 10(1), 1-18.

Hendrastomo, G. (2008). Dilema dan Tantangan Pembelajaran E-learning 1 (The Dilemma and the Challenge of. Majalah Ilmiah Pembelajaran, 4, 1-13.

Hudaa, Syihaabul, Ahmad Bahtiar dan Nuryani. (2020). Pemanfaatan Teknologi untuk Pengajaran Bahasa Indonesia di Tengah Pandemi Covid-19. Ranah: Jurnal Kajian Bahasa. 9(2). 374-385. doi: https://doi.org/10.26499/rnh.v9i2.2361

Munir. (2009). Pembelajaran Jarak jauh berbasis teknologi Informasi dan Komunikasi. Bandung: Alfabeta.
Puspitasari, P., Sari, P., Putri, J., \& Wuryani, W. (2018). Pengaruh Penggunaan Media Pembelajaran terhadap Motivasi Belajar Mahasiswa IKIP Siliwangi. Parole: Jurnal Pendidikan Bahasa Dan Sastra Indonesia, 1(2), 227-232. https://doi.org/http://dx.doi.org/10.2246 0/p.v1i2p\%25p.243.

Saddhono, K. (2015). Integrating culture in Indonesian language learning for foreign speakers at Indonesian universities. Journal of Language and Literature, 6(2), 273-276. https://doi.org/10.7813/j11.2015/6-2/58

Sianturi, S. R. (2018). Meningkatkan Motivasi Belajar Melalui Evaluasi E-Learning Pada Institusi Keperawatan Di Jakarta Dan Depok. Jurnal Pendidikan Keperawatan Indonesia, 4(2). https://doi.org/10.17509/jpki.v4i2.11563.

Wicaksono, V. D., \& Rachmadyanti, P. (2016). Pembelajaran Blended Learning melalui Google Classroom di Sekolah Dasar. Seminar Nasional Pendidikan PGSD UMS \& HDPGSDI Wilayah Timur.

Waryanto, N. H. (2006). On-line Learning Sebagai Salah Satu Inovasi Pembelajaran. Pythagoras, 2(1), 10-23.

Yaumi, Muhammad. (2018). Media dan Teknologi Pembelajaran. Jakarta: Prenadamedia Group. 